\title{
The Effect of Organizational Culture and the Relationship between Transformational Leadership and Job Satisfaction in Petroleum Sector of Libya
}

\author{
Ibrahim Bin Zahari ${ }^{1} \&$ Adel Mohamed Ali Shurbagi ${ }^{2}$ \\ ${ }^{1}$ Graduate Business School, College of Graduate Studies, Universiti Tenaga Nasional (UNITEN), Malaysia \\ ${ }^{2}$ Graduate School of Business, Universiti Tun Abdul Razak (UniRazak), Malaysia \\ Correspondence: Ibrahim Bin Zahari, Graduate Business School, College of Graduate Studies, Universiti Tenaga \\ Nasional (UNITEN), Malaysia. E-mail: ibrahimz@uniten.edu.my
}

Received: June 15, 2012 Accepted: July 12, $2012 \quad$ Online Published: August 8, 2012

doi:10.5539/ibr.v5n9p89 URL: http://dx.doi.org/10.5539/ibr.v5n9p89

\begin{abstract}
The purpose of this study is to investigate the effect of organizational culture on the relationship between transformational leadership and job satisfaction in petroleum sector with a focus on the National Oil Corporation of Libya (NOC). This research was carried out by measuring the data gathered from the five point Likert scale. The Multifactor Leadership Questionnaire (MLQ), Organizational Culture Assessment Instrument (OCAI) and Job Satisfaction Survey (JSS) were used. Quantitative survey method was applied and a sample of 50 employees from the National Oil Corporation of Libya was selected as a sample random sampling to answer the instrument of the study. SPSS software was used to analyze the data collected based on descriptive statistics (mean, standard deviation, percentage, T-test, and Pearson Correlation Coeffiecient). The findings indicate that the leaders of National Oil Corporation of Libya follow transformational leadership style to manage their organization and the dominant culture in NOC of Libya is Hierarchy culture while the relationship between transformational leadership style, job satisfaction and organizational culture is positive significant relationship.
\end{abstract}

Keywords: National Oil Corporation, transformational leadership, organizational culture, job satisfaction, Libya

\section{Introduction}

The petroleum sector is the most important sector in Libya. The National Oil Corporation (NOC) of Libya which is the focus of the study was established in 1970 and it dominates Libya's oil industry, along with a number of smaller subsidiaries, which combined account for approximately half of the country's oil output. NOC carries out exploration and production operations with other companies under petroleum investment agreements, and market the oil and gas locally and abroad. (Sasi, 2008).

NOC of Libya is a state-owned company and one of the biggest oil producers in Africa. The policy is to promote Libyan economy by developing, managing, and exploring of oil resources (National Oil Corporation, 2008). The choice of NOC of Libya to investigate the relationship between transformational leadership, job satisfaction and the impact of organizational culture in National Oil Corporation of Libya, because Libya is a member of Organization of Petroleum Exporting Countries (OPEC) which holds the largest proven oil reserves and the most important oil-producing countries in Africa and the world. The petroleum sector in Libya is very important because it is the backbone of Libyan economy.

The research is approved by the university through the study conducted by the researcher on a sample of the NOC employees of Libya indicated the importance of conducting such study in order to examine the transformational leadership in Middle East in general and in petroleum sector in Libya in particular.

The rest of this paper is structured as follows: Section 2 presents the literature review and the theory of the study. Section 3 discusses the methodology and data collection. Section 4 analyzes the results, while Section 5 introduces conclusion and recommendation.

\subsection{Problem Statement}

The petroleum sector is very important as it is the backbone of Libyan economy. Libya is one of the most important oil-producing countries in Africa and in the world, and that the interest in this sector is very important. 
Therefore, this sector needs professional leaders who can achieve all the goals of both employees and organizations. An organization that is short of capital may resort to borrowing money, and one in a poor location has the option to move. However an organization with short of leadership has little chance for survival (Yousef, 1998).

The relationships between organizational culture, leadership and job satisfaction have attracted considerable interest from both academics and practitioners and most of these studies have been carried out separately. Much of the interest on these variables is based on the results of the previous studies which have asserted that all these concepts may have an impact on the organizations performance (Suleiman, Azzawi, \& Jerjer, 2003; Yousef, 2001).

Previous research conducted have focused on specific human resource behaviors that are associated with transformational leadership models, as both moderating and mediating effects of organizational culture and commitment respectively in a Western setting. Furthermore, the links between transformational leadership, organizational culture and job satisfaction was examined independently. Yet no study has been conducted to investigate the impact of organizational culture on the relationship between transformational leadership and job satisfaction in petroleum sector in the Middle East in general or in Libya in particular. This study, therefore, is unique as it will help to fill this gap in an effort to improve the understanding of the role of leadership in NOC of Libyan setting.

Based on the foregoing, the relationship between transformational leadership, job satisfaction and the impact of organizational culture on these variables were not explored intensively enough in NOC of Libya.

\subsection{Research Objectives}

This paper has four objectives; the first one aims to determine the nature of the relationship between transformational leadership and organizational culture (clan, adhocracy, market and hierarchy) in NOC of Libya, the second aims to determine the nature of the relationship between transformational leadership and job satisfactions in the NOC of Libya, the third aims to determine the nature of the relationship between organizational culture (clan, adhocracy, market and hierarchy) and job satisfaction in NOC of Libya, the fourth aims to determine the impact of organizational culture (clan, adhocracy, market and hierarchy) on the relationship between transformational leadership and job satisfaction in NOC of Libya. Based on the research objectives stated, the following research questions were addressed:

Q1. Is there any relationship between transformational leadership and organizational culture (clan, adhocracy, market and hierarchy) in NOC of Libya?

Q2. Is there any relationship between transformational leadership and job satisfactions in NOC of Libya?

Q3. Is there any relationship between organizational culture (clan, adhocracy, market and hierarchy) and job satisfaction in NOC of Libya?

Q4. Is there any impact of organizational culture (clan, adhocracy, market and hierarchy) on the relationship between transformational leadership and job satisfaction in NOC of Libya?

\section{Literature Review}

\subsection{Transformational Leadership}

The term of transformational leadership was created by the politologist, Burns, 1978; but was subsequently developed by Bass, Avolio, Jung and Berson, (2003), until it reached its current importance (Avolio \& Yammarino, 2002; Bass, 1985). Transformational leaders are leaders who motivate followers via inspiration. The followers are offered challenges and support personality development. Concentration on the intangible qualities, such as shared ideas, shared values and vision in an effort to build up good relationships inside the organization (Bass, 1985). According to Bass, Avolio, Jung and Berson (2003), the dimensions of transformational leadership are as following:

1. Idealized influence (attributed) the leader shares risks with subordinates and is consistent in behavior where ethics, principles, and values are concerned. The relationship between the leader and subordinates does not based on the formal institutional rules and regulations, rewards or punishments rather it is based on personal understanding.

2. Idealized influence (behavior) emphasizes on a collective sense of mission and values, as well as acting upon these values (Molero, Cuadrado, Navas, \& Morales, 2007).

3. Inspirational motivation leaders motivate and inspire those around them by providing the meaning and challenge to the followers' work. 
4. Intellectual stimulation leaders stimulate the followers' efforts as innovative and creative by questioning assumptions, reframing problems, and approaching old situations in new ways.

5. Individualized consideration leaders pay special attention to each individual's needs for achievement and growth by acting as a coach or mentor.

\subsection{Organizational Culture}

Blake and Mouton, (1969), were in fact, the roots of organizational or corporate culture began in the mid nineteenth century were the first authors who mentioned the link between organizational culture and excellence in the late 1960s. However, Hofstede, (1998); is of the view that the concept of organizational culture has became a common parlance two decades after it was used by Blake and Mouton (1969) as an aspect of the organization. Schein (1992) defined organizational culture as a pattern of shared basic assumptions that the group has earned as it solved its problems of external adoption and internal integration that has worked well enough to be considered valid. Therefore, would be taught to the new members as the correct way to perceive, think and feel in relation to those problems. In this definition Schein (1992) also describes organizational culture as being deeper than behavior and artifacts.

\subsection{Types of Organizational Culture}

Many studies had introduced the Competing Values Framework (CVF), and identified four types of culture such as: clan, adhocracy, hierarchy and market culture (Cameron \& Freeman, 1991; Quinn \& Cameron, 1983; Quinn \& Rohrbaugh, 1983). The theory of the Competing Values Framework (CVF) suggests two dimensions; first is differentiation of effectiveness criteria which stress on flexibility, discretion, and dynamism from stability, order and control. Second is differentiation of internal orientation, integration and unity from external orientation, differentiation and rivalry.

Quinn \& Cameron (1983) framework's is adapted for the purpose of this study. The Competing Values Framework (CVF) of Quinn \& Rohrbaugh (1983) is very useful in organizing and interpreting a wide variety of organizational phenomena. Cameron \& Quinn (2006), from this theory, defined organizational culture as being taken for granted the values, underlying assumptions, expectations, collective memories and definitions present in organization. Each quadrant has been given a label to distinguish its most notable characteristics. Cameron and Quinn from this theory suggested four types of culture in organizations such as clan, adhocracy, hierarchy and market which illustrate in Figure 1.

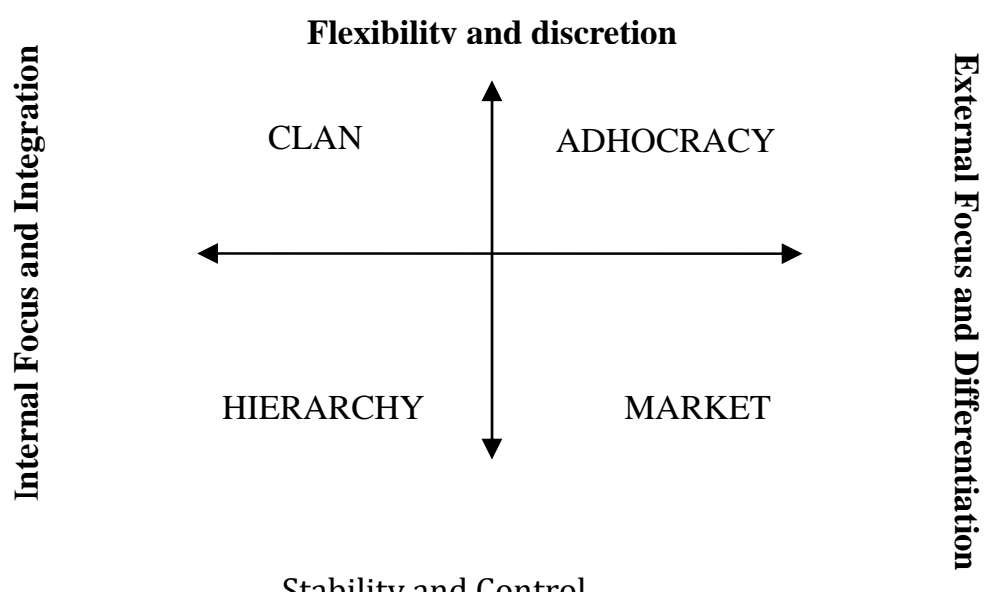

Stability and Control

Figure 1. The Competing Values Framework

Source: Cameron \& Quinn (2006).

\subsubsection{Hierarchy Culture}

Cameron \& Quinn (2006) introduced the hierarchy culture by Weber consists of seven characteristics such as rules, specialization, meritocracy, hierarchy, separate ownership, impersonality, and accountability. These characteristics were deemed highly effective in the accomplishment of the purpose, and were adopted widely in organizations whose major challenge was to generate efficient, reliable, smooth flowing, and predictable output. 


\subsubsection{Market Culture}

The term market is not similar to the marketing function or with consumers in the market place. Rather, it refers to organization that functions as market oriented towards external environment rather than internal affairs. It focused on transactions with suppliers, customers, contractors, regulators and others. The market operates through monetary exchange where the focus is to conduct transactions with other constituencies to create competitive advantage. Profitability, strength in market niches among others are the primary objectives of the organization. The core values for such market-type organizations are competitiveness and productivity.

\subsubsection{Clan Culture}

Clan culture is used because it is similar to family-type organization and it is more families like than economic entities. The common characteristics of clan-type firms were teamwork, employee involvement and corporate commitment of employees.

\subsubsection{Adhocracy Culture}

Adhocracy culture is to foster adaptability, flexibility, and creativity, while uncertainty, ambiguity, and overload of information are common. Adhocracy organization is found in organization such as aerospace, software development, think-tank consulting, and film making. These organizations challenge is to produce innovative products and services and to acquire new opportunities. Adhocracies do not have a centralized power or authority relationship. While, power flows from individual to individual, task team to task team, depend on how the problem is being addressed (Cameron \& Quinn, 2006).

\subsection{Job Satisfaction}

Job satisfaction has been a phenomenon of intense interest among practitioners and researchers for several decades (Cranny et al., 1992; Hwang \& Chi, 2005; Locke, 1976; Spector, 1997; Thomas \& Au, 2002). Many different definitions have focused on job itself, while others are about factors related to job. Practitioners and researchers defined satisfaction as positive feelings or aggressive responses; others defined as the gap between expected gain and actual gain. Spector (1985) viewed job satisfaction as a cluster of evaluative feelings about the job.

\subsection{Determinants of Job Satisfaction}

According to the literature on the job satisfaction there are numerous factors that influence job satisfaction. Worrell (2004) divided these factors into three groups of which the demographic data which includes age, gender, and race; the intrinsic factors that include achievement, recognition, work itself, responsibility, advancement and growth; and the extrinsic factors that include company policy, supervision, relationship with boss, work conditions, relationship with peers and salary. Both the intrinsic factors and extrinsic factors are related to the Two Factor Theory developed by Herzberg (1960).

In the last three decades, academics and researchers have received increasing attention about the new paradigm called transformational leadership where the interest of this study lays. Transformational leadership is widely used in western and non-western countries. Many researchers have pointed out that transformational leadership has been widely used in different sectors in Arabic countries such as Iraq, Saudi Arabia, Jordan and United Arab Emirate (AL-azmi, 2006; Al-Omari, 2004; Al-Sharifi \& Al-Tanah, 2010; Sabri, 2006; Suleiman, et al., 2003). Many studies have also examined this relationship between the variables in the different sectors such as the public sector, health sector, industry sector, services sector, manufacturing sector and the education sector in Arabic countries and Western countries. Therefore, the results between these variables differ and the leaders from these sectors follow transformational leadership to manage their organizations (AL-azmi, 2006; Al-Omari, 2004; Al-Sharifi \& Al-Tanah, 2010; Chen, 2004; Flemming, 2009; Ramey, 2002; Sabri, 2006; Suleiman, et al., 2003).

Less attention has been devoted in comprehending the links between transformational leadership, job satisfaction, and the impact of organizational culture on the relationship between these variables. Numerous studies in the area of job satisfaction have asserted that leadership and organizational culture have significant impact on job satisfaction (Chen \& Francesco, 2000; Lok \& Crawford, 2001; Mathieu \& Zajac, 1990; Williams \& Hazer, 1986).

However, contemporary researchers focused on subordinates' perspective and proposed two main facets of transformational and transactional leadership. Studies suggests that transformational leadership, has a stronger positive effect on employees' attitudes towards job and job environment, which affects work performance, than transactional leadership (Bass, 1985; Burns, 1978). Thus, the study wishes to test transformational leadership theory at the NOC of Libya. Further, Xenikou \& Simosi (2006) suggested that organizational culture and transformational leadership have been theoretically and empirically linked to organizational effectiveness. 
However, transformational leadership, organizational culture and job satisfaction were not explored intensively enough in petroleum sector and more so in NOC of Libya.

\section{Research Methodology}

To gather research data in the current study, questionnaire is preferred due to its ability to collect data from respondents within a limited time frame. The instrument consisted three parts such as transformational leadership, organizational culture and job satisfaction.

\subsection{Instruments and Measurement Scales}

Three instruments were used to measure the variables of the study. These instruments are as following:

1. Multifactor Leadership Questionnaire (MLQ-Form 5X) was used to measure transformational leadership (Avolio \& Bass, 2004). This instrument has been revised several times and is widely used to measure transformational leadership in different countries in the world and the validity and reliability of this scale have been established through previous research (Hartog et al., 1997). Participants were asked to describe their supervisor's leadership behavior on 20 items based on transformational leadership. A five-point Likert scale was used with the responses ranging from ( $1=$ not at all; to $5=$ frequently, if not always). In the MLQ (Form $5 \mathrm{X}$ ), transformational leadership is measured via the use of the five dimensions of transformational leadership. The dimensions were measured by the four items for each, such as Intellectual Stimulation, Idealized Influence (behavior), Idealized Influence (attributed) Inspirational Motivation, and Individualized Consideration.

2. The Organizational Culture Assessment Instrument (OCAI) developed by Cameron and Quinn (2006) as defined by the Competing Values Framework will be implemented in this study. The OCAI questionnaire was used to obtain an insight into the organizational culture based on the OCAI which divided the organizational culture into four types namely, Clan, Adhocracy, Market and Hierarchy Culture.

This survey instrument requires the sample to respond to six key dimensions. According to Cameron and Quinn (2006), the OCAI dimensions range from, dominant characteristics, organizational leadership, management of employees, organization glue, strategic emphasis and the criteria for success. Each of the six dimensions has four alternative answers which brings the total items of the OCAI questionnaire to 24 items. A Likert scale was used in which the respondents rate each alternative for each item on a scale from $(1=$ strongly agree; to $5=$ strongly disagree).

3. The Job Satisfaction Survey (JSS) developed by Spector (1997) was used to measure job satisfaction. Based on Spector (1997) the original JSS includes 36 items. Therefore, in the current study only 20 items from JSS were used to measure five facets of job satisfaction such as supervision, benefits, rewards, operating procedure and co-workers satisfaction. The reason for that is all the studies which have been carried out in the Libyan environment have asserted that these facets are the most important facets that have an impact on job satisfaction in the Libyan environment. Therefore, the validity and reliability of MLQ, the OCAI and the JSS scales have been established through previous research. The Cronbach's Alpha coefficient of the instruments was above 0.70 (Al-Sharifi \& Al-Tanah, 2010; Spector, 1997; Twati \& Gammack, 2006). In the current study the Cronbach's Alpha coefficient of transformational leadership, organizational culture and job satisfaction were $0.96,0.97,0.92$ respectively.

\subsection{Participants}

To investigate the nature of the relationship between transformational leadership, job satisfaction and the effects of organizational culture on the relationship between these variables in NOC of Libya, out of 55 questionnaires were distributed to local employees in NOC of Libya. 50 questionnaires were returned and were suitable for data analysis, giving a response rate of 90.9 percent. The sample random sampling was used in this study. The data were then analyzed using Statistical Package for Social Sciences (SPSS.16).

\section{Empirical Results}

Data was analyzed through descriptive statistical methods with mean, standard deviation, percentage, T-test, and Pearson Correlation Coefficient. Table 1 contains profile of the respondents of the study. From the table 1 , it was obvious that $60 \%$ of the respondents were male while the rest comprised of females. $32 \%$ of respondents were within age of $26-35$ years, while $52 \%$ of them were from $36-45$ years of age and $16 \%$ of the respondents were from the 46-55 years of age.

As mentioned earlier, the respondents for this study employees in NOC of Libya, approximately 26\% have high school level of education, while $44 \%$ of them have undergraduate level of education, and $30 \%$ have graduate level. $38 \%$ of the respondents were single and $62 \%$ of them were married. About $46 \%$ of the respondents their 
salaries less than $700 \mathrm{DL}$, and $32 \%$ of them earned between $700-1100 \mathrm{DL}$, while $22 \%$ their income from 1101-1500 DL (1 DL = 2.30 RM).

Finally, there were $10 \%$ of respondents had less than 5 years of working experience, while $36 \%$ of them had from 5-10 years of working experience, and 18\% had from 11-15 years of working experience. On the other hand, $26 \%$ of them had from 16-20 years of working experience, while only $10 \%$ had from $21-25$ years of working experience. All this information is given in Table 1 below.

Table 2 shows the percentages, means, and standard deviations related to the perceptions of respondents of the NOC of Libya about transformational leadership, organizational culture and job satisfaction in their organization. According to table 2 the respondents of the study asserted that the leaders of NOC follow transformational leadership to manage their organization. From the data the mean of the five dimensions of transformational leadership such as intellectual stimulation, idealized influence (behavior), idealized influence (attributed), individualized consideration and inspirational motivation were 2.61, 3.05, 3.14, 2.72 and 2.57 respectively, while the standard deviation of them were $0.72,1.0,1.2,0.90$ and 0.85 respectively. These findings supported the results of the previous studies which pointed out that the leaders of the organizations in Arabic countries follow transformational leadership style to manage their organizations (AL-azmi, 2006; Al-Omari, 2004; Al-Sharifi \& Al-Tanah, 2010; Sabri, 2006; Suleiman, et al., 2003). These studies have been carried out in different sectors such as public sector, industry sector, education sector, and services sector while the current study has carried out in petroleum sector in Libya.

However, the results show that the means of clan, adhocracy, market and hierarchy culture are 2.65, 2.36, 2.70, and 2.76 respectively, while the standard deviations of them are $0.89,0.70,0.83$ and 0.83 respectively. Therefore, as can be seen from Table 2, the participants of NOC have pointed out the dominant culture in the NOC is Hierarchy culture. This result consistent with previous studies by Twati (2006) who pointed out that the dominant culture in Banking and Oil sector in Libya was Hierarchy culture. Cameron and Quinn (2006) argued that organisations take turns at different cultures as they progress from clan culture to adhocracy culture, market culture and finally hierarchy culture. The study at NOC fit in the hierarchy culture at this point.

On the other hand, the respondents asserted that they were satisfied with all the facets of job satisfaction such as supervision, benefits, rewards, operating procedure and co-workers satisfaction and the mean of these facets are $2.71,2.68,2.76,2.66$ and 2.57 respectively while the standard deviation of them are $0.75,0.86, .073,0.83$ and 0.79 respectively. This result consistent with previous studies by Alesayoi (2003) who pointed out that the most job satisfaction facets can impact Libyan environment are supervision, benefits, rewards, operating procedure and co-workers satisfaction.

Table 1. Respondents' Profile

\begin{tabular}{lll|lll}
\hline Contents & frequency & Percent & Contents & frequency & Percent \\
\hline Age & & & Education Level: & & \\
26-35 years & 16 & $32 \%$ & High School & 13 & $26 \%$ \\
$36-45$ years & 26 & $52 \%$ & Undergraduate & 22 & $44 \%$ \\
$46-55$ years & 8 & $16 \%$ & Graduate & 15 & $30 \%$ \\
Total & $\mathbf{5 0}$ & $\mathbf{1 0 0 \%}$ & Total & $\mathbf{5 0}$ & $\mathbf{1 0 0} \%$ \\
\hline Gender & & & Income: & & $46 \%$ \\
Male & 30 & $60 \%$ & Less than 700 DL & 23 & $32 \%$ \\
Female & 20 & $40 \%$ & $700-1100$ DL & 16 & $22 \%$ \\
& & & $1101-1500$ DL & 11 & $\mathbf{1 0 0 \%}$ \\
Total & $\mathbf{5 0}$ & $\mathbf{1 0 0} \%$ & Total & $\mathbf{5 0}$ & $10 \%$ \\
\hline Marital Status: & & Work Experience: & & $36 \%$ \\
Single & 19 & $38 \%$ & Less than 5 years & 5 & $18 \%$ \\
Married & 31 & $62 \%$ & $5-10$ years & 18 & $26 \%$ \\
Total & $\mathbf{5 0}$ & $\mathbf{1 0 0} \%$ & $11-15$ years & 9 & $10 \%$ \\
& & $16-20$ years & 13 & $\mathbf{1 0 0 \%}$ \\
\hline
\end{tabular}

From discussion above and table 2, it could be concluded that the leaders of NOC follow transformational leadership style when they manage their organization, while the dominant culture in NOC is Hierarchy culture and the respondents were satisfied with all the facets of job satisfaction. 
Table 2. Statistics Descriptive of Transformational Leadership, Organizational Culture and Job Satisfaction

\begin{tabular}{lll}
\hline Variable \& Dimensions & Mean & Std. Dev \\
\hline Transformational Leadership & \multicolumn{2}{l}{0.72} \\
Intellectual Stimulation (IS) & 2.61 & 1.0 \\
Idealized Influence (behavior) (IIB) & 3.05 & 1.2 \\
Idealized Influence (attributed) (IIA) & 3.14 & 0.90 \\
Inspirational Motivation (IM) & 2.72 & 0.85 \\
Individualized Consideration( IC) & 2.57 & \\
\hline Organizational Culture & & 0.89 \\
Clan (CC) & 2.65 & 0.70 \\
Adhocracy (AC) & 2.36 & 0.83 \\
Market (MC) & 2.70 & 0.83 \\
Hierarchy (HC) & 2.76 & \\
\hline Job Satisfaction & & 0.75 \\
Supervision Satisfaction (SS) & 2.71 & 0.86 \\
Benefits Satisfaction (BS) & 2.68 & 0.73 \\
Rewards Satisfaction (RS) & 2.76 & 0.83 \\
Operating procedure and Satisfaction (OPS) & 2.66 & 0.79 \\
Co-Workers Satisfaction (CWS) & 2.57 & \\
\hline
\end{tabular}

Table 3 shows the relationship between the variables of the current paper, transformational leadership, organizational culture and job satisfaction which were 0.89 and 0.91 respectively. Besides, the relationship between organizational culture and job satisfaction was 0.89. Based on the results of the relationship between these variables it could be concluded that the relationship between transformational leadership style, organizational culture and job satisfaction is significant and positive relationship.

Table 3. Pearson correlation between Transformational Leadership, Organizational Culture and Job Satisfaction

\begin{tabular}{lll}
\hline Variables & Organizational culture & Job satisfaction \\
\hline Transformational leadership & $0.89^{* *}$ & $.091^{* *}$ \\
Organizational culture & & $0.89^{* *}$ \\
\hline Note: ${ }^{* *}$ Correlation is significant at the 0.01 level (2-tailed).
\end{tabular}

\section{Conclusions, Recommendations \& Limitations}

Previous studies have examined the link between leadership paradigms and behaviors (Al-Omari, 2004; Al-Sharifi \& Al-Tanah, 2010) and the results of these studies differ. The current paper concluded that the leaders of NOC follow transformational leadership style when they manage their organization while the dominant culture is Hierarchy culture and the respondents were satisfied with all the facets of job satisfaction. Thus, the results suggest that there is a relationship between transformational leadership, job satisfaction, and the effects of organizational culture on the relationship between transformational leadership and job satisfaction in National Oil Corporation of Libya. The concept of leadership is a very important topic for research in National Oil Corporation of Libya in particular and the petroleum sector in general. The study, further conclude that the relationship between transformational leadership, organizational culture and job satisfaction is significant positive relationship. The study may draw attention on the need to strengthen the leadership style, model, approaches and direction for petroleum sector for future development. Certainly business leaders in petroleum sector should play a dominant role in industrial development in Libya. Finally, the study stress the important of human capital development in petroleum sector in particular the development of leadership to spearhead the economic development of Libya. The scope of the study is limited to the employees of NOC based at the Headquarter in Tripoli, Libya only due to political uncertainty.

\section{References}

AL-Azmi, M. B. (2006). Transference leadership and its relation with managerial creative: surveying study on civil employees department ministry of interior. (Unpublished master's thesis). Naif Arab University, Saudi Arabia.

Alesayoi, L. A. (2003). The effect of environment organizational on the job satisfaction: empirical study in industry sector. (Unpublished master's thesis). Academy of higher studies, Libya. 
Al-Omari, M. N. (2004). The relationship between the characteristics of transformational leadership and the availability of the principles of Total Quality Management. (Unpublished master's thesis). King Saud University, Riyadh.

Al-Sharifi, A. M., \& Al-Tanah, M. M. (2010). The degree of practicing transformational leadership by private secondary school principals in the UAE. Journal of Human Sciences, 45(7), 1-28.

Avolio, B. J., \& Bass, B. M. (2004). Multifactor leadership questionnaire: manual and sampler set. Mind Garden, Inc.

Avolio, B. J., \& Yammarino, F. J. (2002). Transformational and charismatic leadership: The road ahead. New York: Erlbaum.

Bass, B. M. (1985). Leadership and performance beyond expectations. Free Press.

Bass, B. M., Avolio, B. J., Jung, D. I., \& Berson, Y. (2003). Predicting unit performance by assessing transformational and transactional leadership. Journal of applied psychology, 88(2), 207.

Blake, R. R., \& Mouton, J. S. (1969). Building a Dynamic Corporation through Grid Organization Development. Addison-Wesley.

Burns, J. M. (1978). Leadership. New York: Harper and Row Publishers.

Cameron, K. S., \& Freeman, S. J. (1991). Cultural congruence, strength, and type: Relationships to effectiveness. Research in organizational change and development, 5(1), 23-58.

Cameron, K. S., \& Quinn, R. E. (2006). Diagnosing and changing organizational culture: Based on the competing values framework. Jossey-Bass.

Chen, L. Y. (2004). Examining the effect of organization culture and leadership behaviors on organizational commitment, job satisfaction, and job performance at small and middle-sized firms of Taiwan. Journal of American Academy of Business, 5(1/2), 432-438.

Chen, Z. X., \& Francesco, A. M. (2000). Employee demography, organizational commitment, and turnover intentions in China: Do cultural differences matter? Human Relations, 53(6), 869-887. http://dx.doi.org/10.1177/0018726700536005

Cranny, C. J., Smith, P. C., \& Stone, E. (1992). Job satisfaction: How people feel about their jobs and how it affects their performance. New York: Lexington.

Flemming, P. L. (2009). A study of the relationship between transformational leadership traits and organizational culture types in improving performance in public sector organizations: A Caribbean perspective. (Unpublished doctoral dissertation). Capella University, USA.

Hartog, D. N., Muijen, J. J., \& Koopman, P. L. (1997). Transactional versus transformational leadership: An analysis of the MLQ. Journal of occupational and organizational psychology, 70(1), 19-34. http://dx.doi.org/10.1111/j.2044-8325.1997.tb00628.x

Hofstede, G. (1998). Attitudes, values and organizational culture: Disentangling the concepts. Organization studies, 19(3), 477-492. http://dx.doi.org/10.1177/017084069801900305

Hwang, I. S., \& Chi, D. J. (2005). Relationships among internal marketing, employee job satisfaction and international hotel performance: An empirical study. International Journal of Management, 22(2), 285-293.

Locke, E. A. (1976). The nature and causes of job satisfaction. In M. D. Dunnette (Ed.), Handbook of industrial and organizational psychology. Chicago, IL: Rand McNally College Publishing.

Lok, P., \& Crawford, J. (2001). Antecedents of organizational commitment and the mediating role of job $\begin{array}{llll}\text { satisfaction. Journal of } & \text { Managerial }\end{array}$ http://dx.doi.org/10.1108/EUM0000000006302

Mathieu, J. E., \& Zajac, D. M. (1990). A review and meta-analysis of the antecedents, correlates, and consequences of organizational commitment. Psychological Bulletin, 108(2), 171-194. http://dx.doi.org/10.1037/0033-2909.108.2.171

Molero, F., Cuadrado, I., Navas, M., \& Morales, J. (2007). Relations and effects of transformational leadership: a comparative analysis with traditional leadership styles. The Spanish journal of psychology, 10(2), 358-368.

National Oil Corporation. (2008). Gale directory of company histories: National Oil Corporation. Retrieved 10, February, 2010, from http://www.answers.com/topic/national-oil-corporation. 
Quinn, R. E., \& Cameron, K. (1983). Organizational life cycles and shifting criteria of effectiveness: Some preliminary evidence. Management science, 29(1), 33-51. http://dx.doi.org/10.1287/mnsc.29.1.33

Quinn, R. E., \& Rohrbaugh, J. (1983). A spatial model of effectiveness criteria: Towards a competing values approach to organizational analysis. Management science, 29(3), 363-377. http://dx.doi.org/10.1287/mnsc.29.3.363

Ramey, J. W. (2002). The relationship between leadership styles of nurse managers and staff nurse job satisfaction in hospital settings. (Unpublished Master's thesis). Marshall University, Huntington, West Virginia.

Sabri, H. A. (2006). Leadership styles dominant and the requirements shift to the Knowledge Economy. Zaytoonah University of Jordan, 1-22.

Sasi, T. A. (2008). Antecedents of human resource management practices: Case study analyses of the National Oil Corporation in Libya. (Unpublished doctoral dissertation). Tun Abdul Razak University, Kuala Lumpur.

Schein, E. H. (1992). Organizational culture and leadership. Jossey-Bass San Francisco.

Spector, P. E. (1985). Measurement of human service staff satisfaction: Development of the Job Satisfaction Survey. American journal of community psychology, 13(6), 693-713. http://dx.doi.org/10.1007/BF00929796

Spector, P. E. (1997). Job satisfaction: Application, assessment, cause, and consequences. Sage Publications, Inc.

Suleiman, M. M. S., Azzawi, M. A. M., \& Jerjer, A. M. S. (2003 May). The impact of dimensions of transformational leadership in the management of organizational change. Paper presented at the International Scientific Conference of the Eighth Annual Change Management and Knowledge Society, Mosul, Iraq.

Thomas, D. C., \& Au, K. (2002). The effect of cultural differences on behavioral responses to low job satisfaction. Journal of International Business Studies, 33(2), 309-326. http://dx.doi.org/10.1057/palgrave.jibs.8491018

Twati, J. M. (2006). Societal and organisational culture and the adoption of management information systems in Arab countries. (Unpublished doctoral dissertation). Griffith University, Australia.

Twati, J. M., \& Gammack, J. G. (2006). The impact of organisational culture innovation on the adoption of IS/IT: The case of Libya. Journal of enterprise information management, 19(2), 175-191. http://dx.doi.org/10.1108/17410390610645076

Williams, L. J., \& Hazer, J. T. (1986). Antecedents and consequences of satisfaction and commitment in turnover models: A reanalysis using latent variable structural equation methods. Journal of applied psychology, 71(2), 219-231. http://dx.doi.org/10.1037/0021-9010.71.2.219

Worrell, T. G. (2004). School psychologists's job satisfaction: Ten years later of the Virginia Polytechnic Institute and State University. (Unpublished doctoral dissertation). Virginia Tech, Virginia

Xenikou, A., \& Simosi, M. (2006). Organizational culture and transformational leadership as predictors of business unit performance. Journal of Managerial Psychology, 21(6), 566-579. http://dx.doi.org/10.1108/02683940610684409

Yousef, D. A. (1998). Correlates of perceived leadership style in a culturally mixed environment. Leadership \& Organization Development Journal, 19(5), 275-284. http://dx.doi.org/10.1108/01437739810234341

Yousef, D. A. (2001). Islamic work ethic: A moderator between organizational commitment and job satisfaction in a cross-cultural context. Personnel Review, 30(2), 152-169. http://dx.doi.org/10.1108/00483480110380325 